\title{
Wildlife Responses to Long-Term Application of Biosolids to Grasslands in North Carolina
}

\author{
Brian E. Washburn ${ }^{1}$ and Michael J. Begier ${ }^{2}$ \\ Authors are ${ }^{1}$ Research Wildlife Biologist, US Dept of Agriculture, Wildlife Services, National Wildlife Research Center, Sandusky, OH 44870, USA; and \\ ${ }^{2}$ National Coordinator for Airports, US Dept of Agriculture, Wildlife Services, Washington, DC 20250-3402, USA.
}

\begin{abstract}
Applications of biosolids to grassland areas might alter the attractiveness of those habitats to wildlife. For the past 21 yr, biosolids have been applied annually to grasslands at Marine Corps Air Station (MCAS) Cherry Point, Havelock, North Carolina. During 2003-2005, we conducted a study to determine if the long-term application of biosolids has altered plant communities and/or wildlife use of grassland areas. Ten circular 1.7-ha plots were established: five plots served as controls (untreated) and five plots were located in areas that received biosolids. We monitored vegetation growth, measured plant community composition, and observed all plots for wildlife activity during December 2003 through December 2005. Long-term application of biosolids to grasslands at MCAS Cherry Point has altered the botanical structure and composition of those areas. Plant communities in grassland areas receiving biosolids were taller $(P<0.001)$, denser $(P<0.001)$, and less diverse $(P<0.001)$ than control areas that did not receive biosolids. Biosolids study plots were dominated by tall fescue (Lolium arundinaceum [Schreb.] S.J. Darbyshire), whereas control plots consisted of a diversity of grasses, forbs, and woody plants. We observed more $(P<0.001)$ total birds $\cdot 3$-min survey ${ }^{-1}$ using biosolids treatment plots $(6.7 \pm 0.5$ birds; $\overline{\mathrm{x}} \pm \mathrm{SE})$ than birds using control $(2.6 \pm 0.2$ birds) plots. Species-specific differences in use of biosolids and control grasslands did occur and was often related to season. We observed no differences in white-tailed deer (Odocoileus virginianus) use of biosolids and control areas when examining information from two types of deer surveys. Long-term biosolids application to cool-season grasslands alters plant communities and favors use of those areas by some grassland birds.
\end{abstract}

\section{Resumen}

La aplicación de biosólidos en áreas de pastizales podría alterar el nivel de uso de dichos hábitats para la fauna silvestre. Durante los últimos 21 años se han aplicado biosólidos anualmente a los pastizales de la Estación Aérea de Cuerpo de la Marina (MCAS) Cherry Point, Havelock, North Carolina. Durante el período entre 2003-2005 se condujo un estudio para determinar si la aplicación de largo plazo de biosólidos ha alterado las comunidades vegetales y/o el uso de áreas de pastizal por parte de la fauna silvestre. Se establecieron 10 parcelas circulares de 1.7 ha: cinco parcelas sirvieron de control y cinco parcelas se establecieron en áreas tratadas con biosólidos. Se monitoreó el crecimiento de la vegetación, se midió la composición botánica de la comunidad vegetal y se observó la actividad de la fauna silvestre en todas las parcelas entre Diciembre 2003 y Diciembre 2005. La aplicación de largo plazo de biosólidos a los pastizales del MCAS Cherry Point ha alterado la estructura y composición botánica de esas áreas. Las comunidades vegetales de áreas de pastizal tratadas con biosolidos tuvieron mayor altura $(P<0.001)$, densidad $(P<0.0001)$, y fueron menos diversas $(P<0.0001)$ que las parcelas que no fueron tratadas con biosólidos (control). Las parcelas tratadas con bisólidos estuvieron dominadas por festuca alta (Lolium arundinaceum [Schreb.] S.J. Darbyshire), mientras que las parcelas del control consistieron de una diversidad de pastos, hierbas, y plantas leñosas. Se observaron más $(P<0.0001)$ aves totales $\cdot$ relevamiento de 3 minutos utilizando parcelas tratadas con biosólidos $(6.7 \pm 0.5$ aves; $\overline{\mathrm{x}} \pm \mathrm{SE}$ ) comparado con parcelas del control (2.6 \pm 0.2 aves). Se detectaron diferencias en el uso de parcelas tratadas y control por diferentes especies de aves que frecuentemente estuvieron asociadas con la estación del año. No se observaron diferencias en el uso de parcelas tratadas y control por parte de venados (Odocoileus virginianus) al examinar los resultados de dos tipos de relevamiento de venados. La aplicación de largo plazo de biosólidos a pastizales dominados por especies microtérmicas altera las comunidades vegetales y favorece el uso de dichas áreas por algunas aves de praderas.

Key Words: bird habitat, botanical structure, municipal biosolids, plant composition, species diversity, white-tailed deer

\section{INTRODUCTION}

Research was funded by the US Dept of the Navy and the US Dept of Agriculture.

At the time of research, Begier was a wildlife biologist, US Dept of Agriculture, Wildlife Services, MCAS Cherry Point, NC 28533, USA.

Correspondence: Brian E. Washburn, US Dept of Agriculture, Wildlife Services, National Wildlife Research Center, 6100 Columbus Ave, Sandusky, OH 44870, USA. Email: brian.e.washburn@ aphis.usda.gov

Manuscript received 18 September 2009; manuscript accepted 6 October 2010.
Municipal biosolids (i.e., treated and stabilized sewage sludge) are nutrient-rich organic compounds that result from the treatment of municipal wastewater. Land application of municipal biosolids provides benefits (e.g., fertilization and organic matter) to the receiving system, although the level of biosolids application to a given land area must be carefully monitored to avoid the accumulation of heavy metals and limit 
nutrient (e.g., phosphorus) run-off into groundwater and other aquatic systems (Levine et al. 1989; US Environmental Protection Agency [USEPA] 1993; Maguire et al. 2000). Biosolids are commonly used as a soil amendment to agricultural lands (Lerch et al. 1990; Vasseur et al. 2000; Gaskin et al. 2003) to enhance rangeland plant production (Fresquez et al. 1990; Mata-Gozález et al. 2006) in forestry applications (Dutch and Wolstenholme 1994; Henry et al. 1994), or in ecological restoration efforts of degraded lands (Sopper 1993; Moreno-Penaranda et al. 2004).

Land application of biosolids into agricultural systems, rangelands, and degraded ecosystems (e.g., minesoils) typically results in improvements in soil fertility and increased plant biomass and cover, which is beneficial in regard to crop and forage production (Kiemnec et al. 1987; Cogger et al. 2001; Gaskin et al. 2003), decreasing soil erosion (Meyer et al. 2004), and restoring vegetation to ecologically disturbed areas (Sopper 1993; Moreno-Penaranda et al. 2004; Evanylo et al. 2005). Biosolids act as a slow-release fertilizer and replenish organic matter and nutrients into impoverished soils (Fresquez et al. 1990; White et al. 1997). Much of the research regarding land applications of biosolids has occurred on western rangelands in semi-arid environments, whereas the effects of biosolids application on vegetation within existing cool-season and native grasslands in the eastern United States is unknown.

Wildlife responses to the land application of biosolids, either short- or long-term, have not been well studied. Long-term applications of biosolids to grasslands and rangelands might alter the attractiveness of these habitats to wildlife by inducing changes in the characteristics of the plant communities contained therein. Such information is important for land use planners and wildlife managers attempting to assess the environmental impacts of biosolids application into grassland ecosystems and habitats.

The objectives of this study were to compare 1) plant communities, 2) bird use, and 3) white-tailed deer use of grassland habitats with and without the long-term application of biosolids. The National Wildlife Research Center Institutional Animal Care and Use Committee approved procedures involving birds and white-tailed deer (QA-1056).

\section{METHODS}

\section{Study Site}

We conducted this study from December 2003 through December 2005 at Marine Corps Air Station (MCAS) Cherry Point, Craven County, North Carolina (lat 34 $54^{\prime} \mathrm{N}$, long $\left.76^{\circ} 52^{\prime} \mathrm{W}\right)$. MCAS Cherry Point is a US Dept of Defense aviation facility located on the south side of the Neuse River basin adjacent to Havelock, North Carolina, approximately $80 \mathrm{~km}$ inland from the Atlantic Ocean. Mean annual precipitation at the study area is $1300 \mathrm{~mm} \cdot \mathrm{y}^{-1}$ with $60 \%$ typically falling as rain during April through September (Goodwin 1989). The average daily temperature during summer is $26.1^{\circ} \mathrm{C}$. Soils on the study area consisted of Norfolk loamy fine sands (very strongly acidic, well-drained, moderate permeability), Bragg soils altered by construction methods (extremely acidic, well-drained, moderate permeability), and
Rains fine sandy loams (extremely acidic, poorly drained, moderate permeability; Goodwin 1989).

Grassland habitats on the MCAS Cherry Point airfield are managed in accordance with air safety regulations and mowed during the growing season. These grassland areas consist of a variety of plants, whose origins are likely from postairfield construction seeding efforts and from the herbaceous layer of Mesic Pine Flatwoods forest communities (Schafale and Weakley 1990) that surround the airfield grasslands. Dominant plants on the study area included tall fescue (Lolium arundinaceum [Schreb.] S.J. Darbyshire), bahiagrass (Paspalum notatum Flueggé), little bluestem (Schizachyrium scoparium [Michx.] Nash), hairy crabgrass (Digitaria sanguinalis [L.] Scop.), trumpet creeper (Campsis radican [L.] Seem. ex Bureau), goldenrod (Solidago sp. L.), poison ivy (Toxicodendron radicans [L.] Kuntze), and Virginia creeper (Parthenocissus quinquefolia [L.] Planch.).

An integrated wildlife damage management program is conducted at MCAS Cherry Point to reduce the risk of collisions between wildlife (e.g., birds, deer) and military aircraft. Birds common to suburban and grassland areas in coastal areas of North Carolina (e.g., American robin [Turdus migratorius], eastern meadowlark [Sturnella magna], European starling [Sturnus vulgaris], laughing gull [Larus atricilla], and red-tailed hawk [Buteo jamaicensis]) are commonly observed at MCAS Cherry Point. We used the US Dept of Agriculture (USDA), Integrated Taxonomic Information System (ITIS; 2009) as the source for plant and animal scientific nomenclature.

\section{Biosolids Applications and Study Plots}

In November 2003, we established five 1.7-ha control (untreated) and five 1.7-ha biosolids (treated) monitoring plots in the grassland areas of the MCAS Cherry Point airfield (Fig. 1). Biosolids-treated monitoring plots were established in five separate areas within the 53.9 ha of the airfield grasslands that have annually received surface-applied lime-stabilized biosolids at a rate of $7.6 \mathrm{Mg} \cdot \mathrm{ha}^{-1}$ on a dry weight basis (using an average of $194887 \mathrm{~L} \cdot \mathrm{ha}^{-1}$ of water as a carrier) annually during a 17-yr period (1989-2005). Biosolids applications were rotated among the areas through the year resulting in an average of two to three application times - each individual area $\cdot \mathrm{yr}^{-1}$. Control monitoring plots were established in five separate areas within the 530.9 ha of the grasslands on the airfield that have never received any biosolids. Individual plots were at least $0.5 \mathrm{~km}$ apart and were similar in distance to forested areas, runways, and other landscape characteristics. Plant communities in the plots were dominated by herbaceous vegetation, consisting of a variety of grasses, forbs, and woody plants.

\section{Vegetation Measurements}

Throughout the growing season (April through September), we measured plant community characteristics in all plots twice per month during 2004 and 2005. During each plant community sampling effort, ten sample points were randomly selected in each of the 10 circular 1.7-ha plots using a random numbers table. At each sample point, we measured the maximum vegetation height by placing two 1-m sticks vertically $1.5 \mathrm{~m}$ 


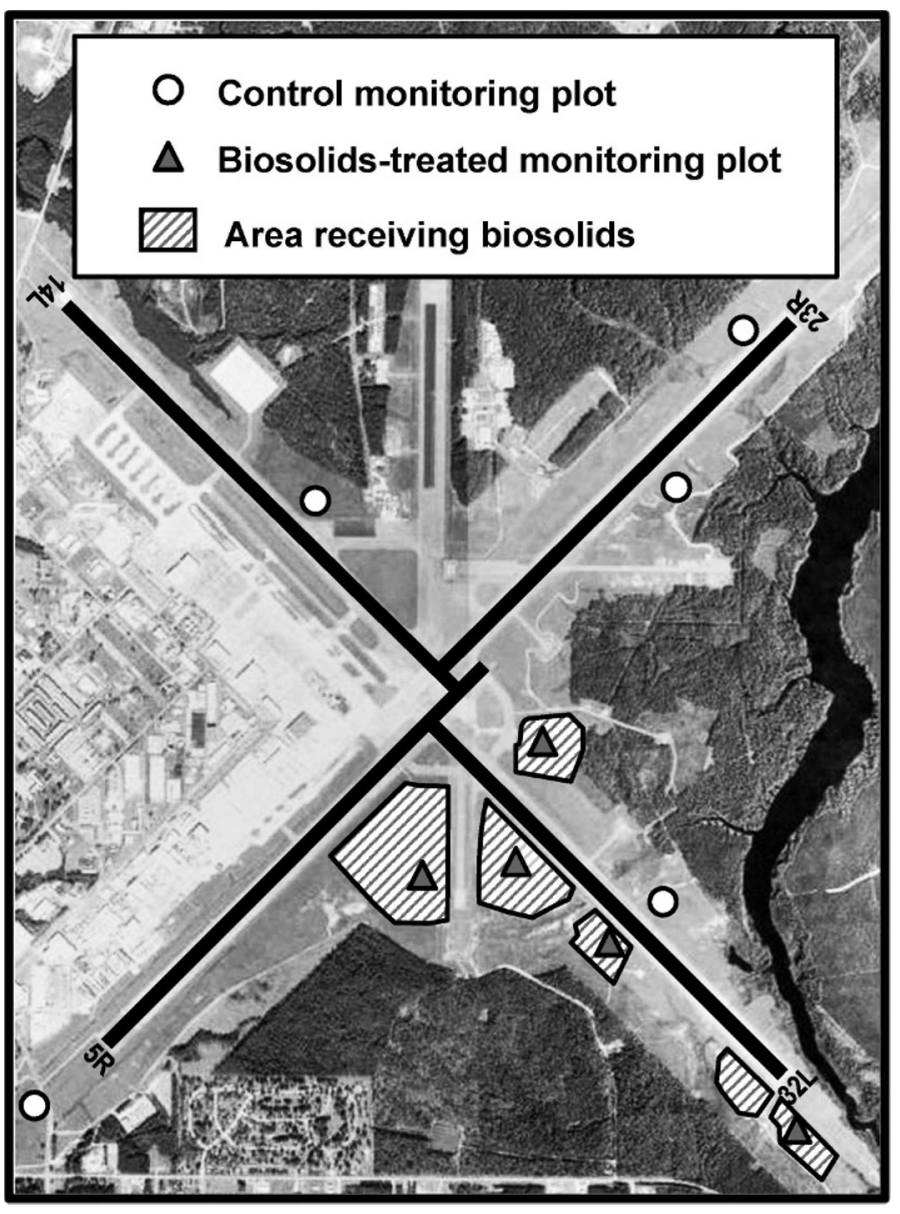

Figure 1. Schematic map of Marine Corps Air Station Cherry Point, Havelock, North Carolina, showing the location of airfield grassland habitats, areas receiving long-term biosolids applications, the location of control (untreated) monitoring plots, and the location of biosolidstreated monitoring plots.

apart with a string connecting the sticks (Washburn and Seamans 2007). We adjusted the height of the string parallel to the top of the tallest plant under the string and recorded the distance from the string to the ground (centimeters). We also measured two visual obstruction readings (VORs) at each sample point (Robel et al. 1970). Plant cover was sampled at six set points along the 1.5 -m string used to measure vegetation height. The plant immediately below each sample point was classified into one of six categories: grasses (including sedges and rushes), forbs and legumes, woody plants (broadleaf, coniferous, and vines), other plants (e.g., lichens, mosses, ferns, and horsetails), bare ground, or litter (i.e., dead plant material, decomposing biosolids).

Plant communities were further described by randomly establishing and sampling $301-\mathrm{m}^{2}$ herbaceous sampling plots of each of the control and biosolids-treated monitoring plots during spring 2004 (25-27 May), fall 2004 (4-6 October), spring 2005 (17-19 May), and fall 2005 (29-31 October). We visually estimated the total vegetative canopy cover $(\%)$, bare ground $(\%)$, litter $(\%)$, and canopy cover (\%) of each individual plant species for each herbaceous sampling plot (Bonham 1989). Plant species richness was determined by identifying and counting the total number of different plant species within each herbaceous sampling plot (Bonham 1989).

\section{Animal Observations}

Birds. Bird surveys (point-counts; Ralph et al. 1995) were conducted each month from December 2003 through December 2005, equally distributed among three different time periods (i.e., morning, mid-day, evening). Bird observations were conducted an average of $4.9 \mathrm{~d} \cdot \mathrm{mo}^{-1}$ (range $=1-9$ ) starting at randomly chosen plots and times. We observed each circular 1.7-ha plot from a fixed point within $30 \mathrm{~m}$ of the plot for 3 min once during each bird survey. The number of birds observed on the ground or on a plant within the plot, flying and feeding over the plot, or flying over the plot was recorded by species and activity.

White-Tailed Deer. We estimated white-tailed deer (Odocoileus virginianus) use of the biosolids and control study areas using two methods. During the study (2003-2005), we conducted a total of 30 white-tailed deer surveys (18 surveys in 2004; 12 surveys in 2005) associated with the circular 1.7-ha control and biosolids-treated study plots. White-tailed deer surveys began approximately $30 \mathrm{~min}$ after sunset. During each survey, we used a pick-up truck to travel to each of the five control and five biosolids-treated study plots. Using a 1000000 candle power spotlight, two observers examined each study plot for a 3-min period and counted the total number of whitetailed deer observed within each plot. In addition to the deer surveys conducted in the study plots, we evaluated historical and concurrent MCAS Cherry Point airfield white-tailed deer surveys $\left(n=140 ; 2.0\right.$ surveys $\left.\cdot \mathrm{mo}^{-1}\right)$ conducted by USDA Wildlife Services during 2000-2005. The entire white-tailed deer spotlight survey route was approximately $26.2 \mathrm{~km}$ in length and was divided into 14 distinct areas. We identified 8 of the 14 areas, four located within areas that did not receive biosolids applications (e.g., control areas) and four located within areas that received biosolids applications (e.g., biosolids-treated areas) and examined these data to determine if differences occurred between these areas in the relative abundance of white-tailed deer. The spotlight survey routes in the selected control and biosolids areas were both a total of $5.0 \mathrm{~km}$ in length.

\section{Statistical Analyses}

Vegetation data (mean vegetation height, VOR, plant community composition) were non-normally distributed and could not be transformed satisfactorily. We used Mann-Whitney U tests (Zar 1996) to compare plant community characteristics between control and biosolids plots for 2004 and 2005 independently.

We wanted to consider only birds actually associated with (e.g., using) the plots and thus removed birds with the "flying" activity codes from the data prior to analyses. Additionally, we assigned all birds observed using the control or biosolidstreated monitoring plots into foraging guilds using a standard classification (DeGraff et al. 1985). The bird observation data were not normally distributed and could not be transformed satisfactorily. Therefore, we compared bird use between control and biosolids-treated monitoring plots using Mann- 
Table 1. Mean ( \pm SE) percent cover of plant community characteristics and plant species richness (species $\cdot \mathrm{m}^{-2}$ ) in control and biosolids-treated monitoring plots located in grassland habitats on the Marine Corps Air Station Cherry Point airfield, Havelock, North Carolina, during spring and fall of 2004 and 2005.

\begin{tabular}{|c|c|c|c|c|c|c|c|c|}
\hline & \multicolumn{4}{|c|}{2004} & \multicolumn{4}{|c|}{2005} \\
\hline & \multicolumn{2}{|c|}{ Spring } & \multicolumn{2}{|c|}{ Fall } & \multicolumn{2}{|c|}{ Spring } & \multicolumn{2}{|c|}{ Fall } \\
\hline & Control & Biosolids & Control & Biosolids & Control & Biosolids & Control & Biosolids \\
\hline Total vegetative cover (\%) & $76.6 \pm 1.2 \mathrm{a}^{1}$ & $85.9 \pm 1.5 b$ & $91.6 \pm 1.1 \mathrm{a}$ & $94.6 \pm 1.3 b$ & $79.8 \pm 1.4 \mathrm{a}$ & $86.4 \pm 1.4 b$ & $89.5 \pm 0.9 \mathrm{a}$ & $87.3 \pm 1.4 \mathrm{a}$ \\
\hline Tall fescue $(\%)$ & $12.8 \pm 1.9 \mathrm{a}$ & $70.5 \pm 2.7 b$ & $17.9 \pm 2.6 \mathrm{a}$ & $75.1 \pm 3.1 \mathrm{~b}$ & $24.1 \pm 2.6 \mathrm{a}$ & $58.3 \pm 3.1 b$ & $14.6 \pm 1.9 \mathrm{a}$ & $57.7 \pm 3.3 b$ \\
\hline Bare ground (\%) & $15.0 \pm 1.6 \mathrm{a}$ & $9.4 \pm 1.2 b$ & $4.2 \pm 0.6 \mathrm{a}$ & $10.2 \pm 2.0 \mathrm{~b}$ & $11.4 \pm 1.6 \mathrm{a}$ & $7.0 \pm 1.1 \mathrm{~b}$ & $4.8 \pm 0.8 \mathrm{a}$ & $6.1 \pm 1.2 \mathrm{a}$ \\
\hline Litter (\%) & $34.0 \pm 2.0 \mathrm{a}$ & $25.7 \pm 1.4 b$ & $10.1 \pm 0.7 \mathrm{a}$ & $6.1 \pm 0.7 b$ & $19.2 \pm 1.2 \mathrm{a}$ & $15.8 \pm 0.9 b$ & $15.6 \pm 0.8 \mathrm{a}$ & $15.6 \pm 1.1 \mathrm{a}$ \\
\hline $\begin{array}{l}\text { Plant species richness } \\
\left(\text { species } \cdot \mathrm{m}^{-2} \text { ) }\right.\end{array}$ & $7.1 \pm 0.2 \mathrm{a}$ & $3.4 \pm 0.2 b$ & $7.1 \pm 0.2 \mathrm{a}$ & $3.5 \pm 0.1 b$ & $6.8 \pm 0.2 \mathrm{a}$ & $4.1 \pm 0.2 b$ & $6.5 \pm 0.1 \mathrm{a}$ & $4.1 \pm 0.1 b$ \\
\hline
\end{tabular}

${ }^{1}$ Means within the same row within a year and season with the same letter are not significantly different (Mann-Whitney $\mathrm{U}$ test; $P>0.05$ ).

Whitney U tests (Zar 1996). We compared the proportion of birds within foraging guilds using control and biosolids-treated monitoring plots using comparison of proportions tests (Zar 1996).

Due to the nature of our white-tailed deer data from the control and biosolids-treated monitoring plots (i.e., limited number of total deer observations), we provide only descriptive statistics. The historical and concurrent white-tailed deer spotlight survey data were non-normally distributed. We compared white-tailed deer relative abundance between control and biosolids areas using a Mann-Whitney U test (Zar 1996). We also compared white-tailed deer abundance among seasons of the year using Kruskal-Wallis tests (Zar 1996). We considered differences significant at $P \leq 0.05$ and conducted all analyses using SAS statistical software version 9.1 (SAS Institute, Cary, NC). Data are presented as mean \pm 1 standard error (SE).

\section{RESULTS}

\section{Plant Communities}

Mean maximum vegetation height during 2004 differed $(P<0.001)$ between the biosolids (treated) and untreated (control) study plots. Vegetation in the biosolids plots $(52.7 \pm 1.7 \mathrm{~cm})$ was taller than vegetation in the control plots $(44.4 \pm 1.4 \mathrm{~cm})$. Similarly, the mean VOR of vegetation in the biosolids plots $(24.1 \pm 1.0 \mathrm{~cm})$ was greater $(P<0.001)$ than the mean VOR of vegetation in the control plots $(15.0 \pm 0.6 \mathrm{~cm})$ during the 2004 growing season.

During 2005, mean maximum vegetation height differed $(P=0.02)$ between the biosolids and control study plots. Vegetation in the biosolids-treated plots $(39.2 \pm 1.2 \mathrm{~cm})$ was taller than vegetation in the untreated plots $(32.2 \pm 0.8 \mathrm{~cm})$. Similarly, the mean VOR of vegetation in the biosolids plots $(15.1 \pm 0.7 \mathrm{~cm})$ was greater $(P<0.001)$ than the mean VOR of vegetation in the control plots $(10.0 \pm 0.4 \mathrm{~cm})$ during the 2005 growing season.

Study plots that received biosolids had more (all $P \leq 0.001$ ) total vegetation canopy cover and less (all $P \leq 0.001$ ) litter than control plots during spring of 2004, fall of 2004, and spring of 2005 (Table 1). Total vegetative canopy cover $(P=0.55)$ and litter levels were similar $(P=0.19)$ between control and biosolids study plots during fall of 2005 (Table 1). On average, grassland areas that did not receive biosolids had twice as many plant species $\cdot \mathrm{m}^{-2}$ compared to areas that received biosolids (Table 1 ).

Both control and biosolids-treated grasslands were comprised of a high proportion of grasses, with forbs, legumes, and woody plants comprising a smaller part of the vegetation (Fig. 2). Control plots were dominated by a variety of grasses (e.g., little bluestem, Panicum spp. L., hairy crabgrass), forbs (e.g., goldenrod), and woody plants and vines (e.g., poison ivy, Virginia creeper), whereas tall fescue, bahiagrass, and trumpet creeper comprised the majority of vegetation in the biosolids study plots. Tall fescue cover was 2.4 to 5.5 times higher (all $P \leq 0.001)$ in the biosolids-treated monitoring plots than in the control plots during spring and fall of 2004 and 2005 (Table 1).

\section{Animal Responses}

Birds. During 118 avian point-count surveys, we observed a total of 6390 individual birds, representing 66 different species.

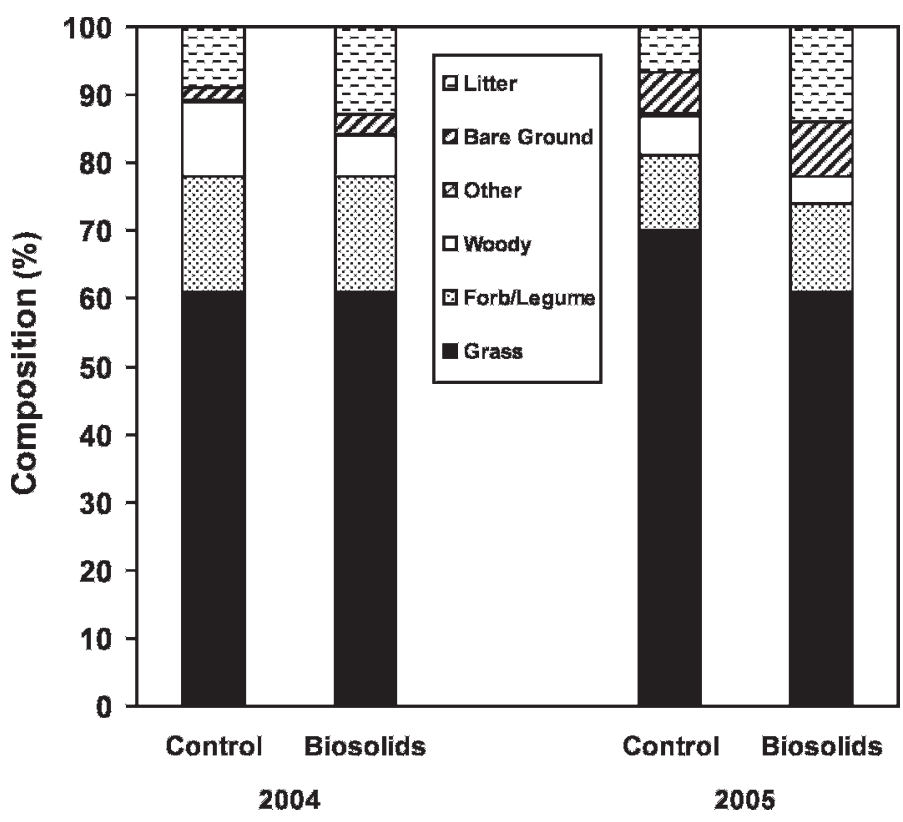

Figure 2. Mean percent cover of plant community characteristics in control and biosolids-treated plots located in grassland habitats on the Marine Corps Air Station Cherry Point airfield, Havelock, North Carolina, during April through September of 2004 and 2005. 
Table 2. Mean $( \pm \mathrm{SE})$ no. of birds observed $\cdot 3$-min survey ${ }^{-1}$ of selected individual species and guilds of birds in control and biosolidstreated monitoring plots at Marine Corps Air Station Cherry Point, Havelock, North Carolina, December 2003 through December 2005.

\begin{tabular}{|c|c|c|}
\hline \multirow[b]{2}{*}{ Species or guild } & \multicolumn{2}{|c|}{ No. of birds $\cdot 3$-min survey ${ }^{-1}( \pm \mathrm{SE})$} \\
\hline & Untreated control & Biosolids-treated \\
\hline Eastern meadowlark & $1.29 \pm 0.09 a^{1}$ & $3.36 \pm 0.23 b$ \\
\hline European starling & $0.12 \pm 0.10 \mathrm{a}$ & $1.60 \pm 0.31 b$ \\
\hline American robin & $0.04 \pm 0.03 a$ & $0.38 \pm 0.11 b$ \\
\hline Mourning dove (Zenaida macroura) & $0.02 \pm 0.01 \mathrm{a}$ & $0.17 \pm 0.06 b$ \\
\hline \multicolumn{3}{|l|}{ Northern bobwhite (Colinus } \\
\hline virginianus) & $0.03 \pm 0.01 \mathrm{a}$ & $0.15 \pm 0.02 b$ \\
\hline Wild turkey (Meleagris gallopavo) & $0.03 \pm 0.02 \mathrm{a}$ & $0.13 \pm 0.05 a$ \\
\hline Turkey vulture (Cathartes aura) & $0.05 \pm 0.02 \mathrm{a}$ & $0.04 \pm 0.01 \mathrm{a}$ \\
\hline Swallows ${ }^{2}$ & $0.51 \pm 0.11 \mathrm{a}$ & $0.19 \pm 0.04 b$ \\
\hline Shorebirds $^{3}$ & $0.09 \pm 0.03 a$ & $0.16 \pm 0.04 b$ \\
\hline Songbirds ${ }^{4}$ & $0.11 \pm 0.02 \mathrm{a}$ & $0.10 \pm 0.02 \mathrm{a}$ \\
\hline Blackbirds $^{5}$ & $0.10 \pm 0.02 \mathrm{a}$ & $0.09 \pm 0.03 a$ \\
\hline Gulls $^{6}$ & $0.04 \pm 0.02 \mathrm{a}$ & $0.07 \pm 0.05 a$ \\
\hline Raptors $^{7}$ & $0.05 \pm 0.01 \mathrm{a}$ & $0.08 \pm 0.01 b$ \\
\hline Crows $^{8}$ & $0.03 \pm 0.01 \mathrm{a}$ & $0.05 \pm 0.02 \mathrm{a}$ \\
\hline Herons and egrets ${ }^{9}$ & $0.00 \pm 0.00 \mathrm{a}$ & $0.02 \pm 0.02 \mathrm{a}$ \\
\hline All species combined & $2.60 \pm 0.20 \mathrm{a}$ & $6.73 \pm 0.46 b$ \\
\hline
\end{tabular}

${ }^{1}$ Means within the same row with the same letter are not significantly different (MannWhitney U test; $P>0.05)$.

${ }^{2}$ Swallows include barn swallows (Hirundo rustica), bank swallows (Riparia riparia), cliff swallows (H. pyrrhonota), rough-winged swallows (Stelgidopteryz serripennis), tree swallows (Tachycineta bicolor), chimney swifts (Chaetura pelagica), and swallows of unknown species.

${ }^{3}$ Shorebirds include black-bellied plovers (Pluvialis squatarola), common snipe (Gallinago gallinago), greater yellowlegs (Tringa melanoleuca), and killdeer (Charadrius vociferus). ${ }^{4}$ Songbirds include 19 species of songbirds.

${ }^{5}$ Blackbirds include red-winged blackbirds (Agelaius phoeniceus), common grackles (Quiscalus quiscalus), and brown-headed cowbirds (Molothrus ater).

${ }^{6}$ Gulls include ring-billed gulls (Larus delawarensis), herring gulls (L. argentatus), and laughing gulls.

${ }^{7}$ Raptors include American kestrels (Falco sparverius), bald eagles (Haliaeetus leucocephaIus), Northern harriers (Circus cyaneus), osprey (Pandion haliaetus), red-tailed hawks, sharp-shinned hawks (Accipiter striatus), and raptors of unknown species.

${ }^{8}$ Crows include American crows (Corvus brachyrhynchos) and fish crows (C. ossifragus).

${ }^{9}$ Herons and Egrets include cattle egrets (Bubulcus ibis) and great blue herons (Ardea herodias).

A total of 884 (13.8\%) of these birds were categorized as "pass flying," a behavior that did not appear to be associated with a study plot. Consequently, these birds were removed from the dataset prior to further analyses.

Overall, we observed birds 5506 times that exhibited a behavior associated with the study plots (e.g., on the ground in the plot). Fifty-five different bird species were observed, but Eastern meadowlarks $(49.8 \%$ of observations), European starlings $(18.4 \%)$, American robins $(4.5 \%)$, and barn swallows $(3.2 \%)$ were the species most frequently observed during the study (Table 2).

We observed more $(P<0.001)$ birds $\cdot 3$-min survey ${ }^{-1}$ using (i.e., on the ground or on plants) study plots that received biosolids $(6.7 \pm 0.5$ birds) than using untreated control plots (2.6 \pm 0.2 birds). The diversity of bird species using biosolidstreated and control monitoring plots was similar. We observed a total of 47 individual bird species using the biosolids-treated monitoring plots, whereas we observed a total of 44 individual bird species using the control plots over the 25 -mo period.

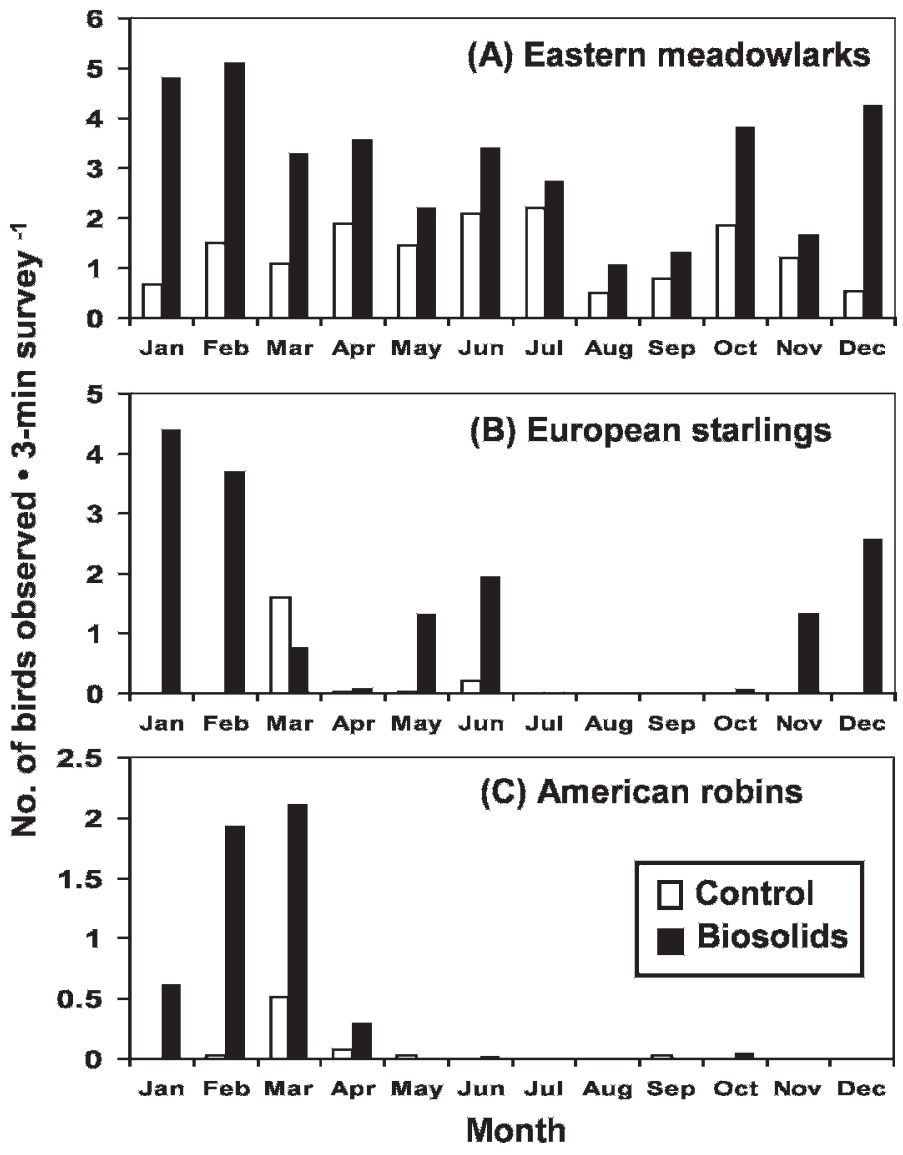

Figure 3. Mean no. of Eastern meadowlarks (A), European starlings (B), and American robins (C) observed - 3-min survey ${ }^{-1}$, by month, in control and biosolids-treated monitoring plots at Marine Corps Air Station Cherry Point, Havelock, North Carolina, December 2003 through December 2005.

Species-specific variation occurred in bird use of study plots that received biosolids and those that did not (control). Although many bird species and guilds did not appear to exhibit a preference between biosolids-treated and control monitoring plots, some patterns were evident (Table 2). Eastern meadowlarks, European starlings, and American robins were more commonly observed using biosolids plots than control plots, whereas swallows (of several species) were observed using control plots more than biosolids-treated monitoring plots during the study. Furthermore, across the year, bird use of control and biosolids-treated plots varied among the species. Swallows used control plots primarily during summer months (May through July). Eastern meadowlarks used control and biosolids-treated monitoring plots throughout the entire year, whereas European starlings and American robins were observed in biosolids plots primarily during winter months (Fig. 3).

Compared to control (untreated) areas, a higher $(P<0.001)$ proportion of omnivorous ground foraging birds and a lower $(P<0.001)$ proportion of insectivorous aerial foraging birds used biosolids-treated monitoring plots during this study (Fig. 4). The proportion of birds within the carnivore, granivore, and insectivore: ground gleaner feeding guilds using the control and biosolids-treated monitoring plots were similar (all $P>0.05$ ). 

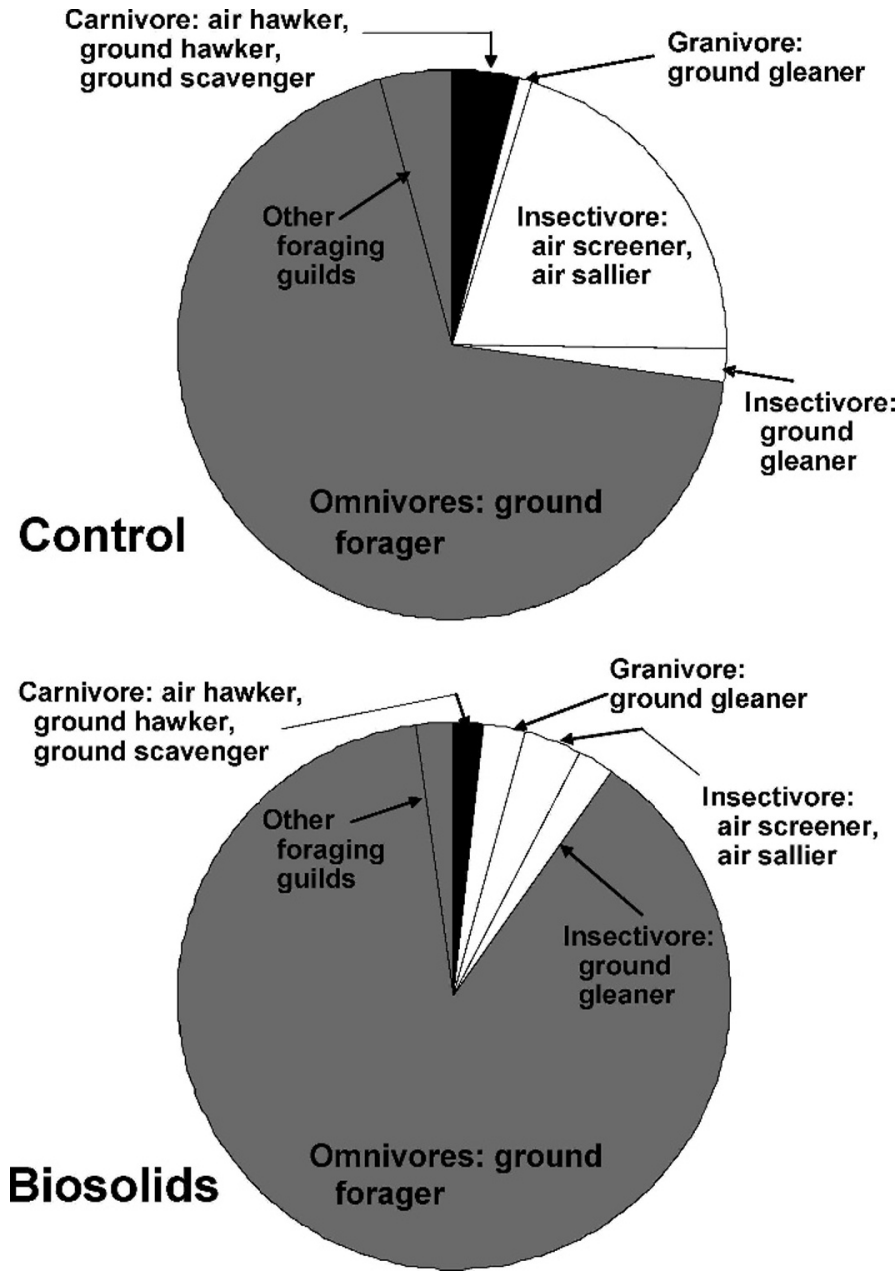

Figure 4. Proportion of birds from various foraging guilds observed using control and biosolids-treated monitoring plots at Marine Corps Air Station Cherry Point, Havelock, North Carolina, December 2003 through December 2005.

White-Tailed Deer. During the white-tailed deer surveys $(n=30)$ conducted within the 1.7-ha study plots during 2004 and 2005 , we counted a total of 28 white-tailed deer $(23$ in control plots and eight in biosolids-treated monitoring plots). The relative abundance of white-tailed deer observed in sampling areas associated with long-term biosolids applications $\left(1.6 \pm 0.1\right.$ deer $\cdot \mathrm{km}$ driven $\left.^{-1}\right)$ was similar $(P=0.94)$ to the relative abundance of deer observed in sampling areas that did not receive biosolids $\left(1.6 \pm 0.1 \mathrm{deer} \cdot \mathrm{km}\right.$ driven $\left.^{-1}\right)$ during airfield spotlight surveys for white-tailed deer $(n=140)$ at MCAS Cherry Point during 2000-2005. White-tailed deer use of the grasslands on the airfield varied $(P=0.003)$ by season; more deer were observed in winter and spring than during fall (Fig. 5).

\section{DISCUSSION}

Long-term application of biosolids has resulted in significant changes to the plant communities within grassland habitats on the MCAS Cherry Point airfield. Grassland areas where

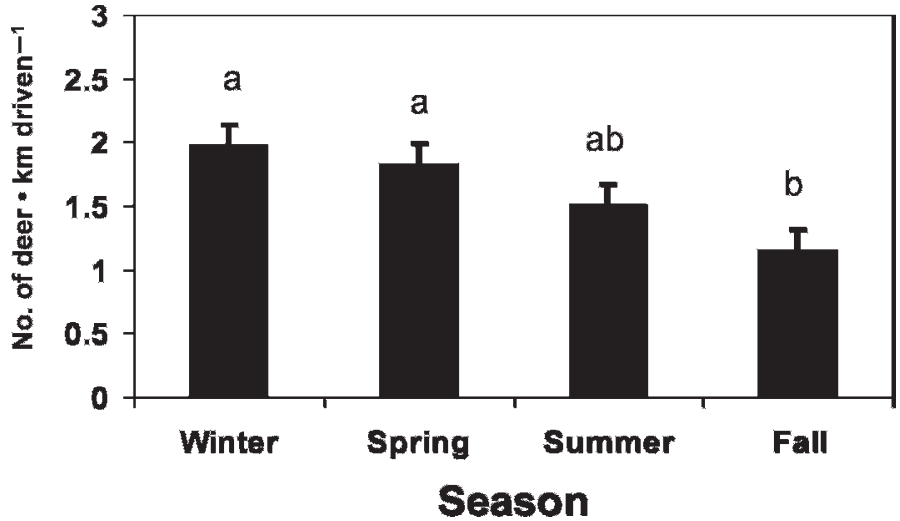

Figure 5. Mean $( \pm \mathrm{SE})$ no. of white-tailed deer observed $\cdot \mathrm{km} \mathrm{driven}^{-1}$, by season, in grassland areas on the airfield at Marine Corps Air Station Cherry Point, Havelock, North Carolina, 2000-2005. Means with the same letter are not significantly different (Mann-Whitney U-test; $P>0.05)$.

biosolids have been applied are taller and denser in structure, contain more tall fescue, and have lower plant species diversity than grassland areas where biosolids have not been applied. Tall fescue is a cool-season perennial sod-forming grass that grows well in temperate climate areas of the United States and is unattractive to many species of grassland wildlife (Barnes et al. 1995; Washburn et al. 2000; Washburn et al. 2007). Tall fescue is extremely competitive and can develop into monocultures, crowding out other plants (Barnes et al. 1995; Washburn et al. 2000). In the biosolids-treated areas, tall fescue appears to have responded very favorably to the high nutrient inputs (e.g., fertilization), potential changes in soils, and other factors associated with biosolids application (Kiemnec et al. 1987; Fresquez et al. 1990; Cogger et al. 2001). Likely, most other plants were competitively excluded from these areas due to the increased growth of tall fescue. Simpler plant communities (e.g., low in structural and plant species diversity) provide fewer foraging opportunities for wildlife, either by providing little forage for herbivores or by having less diverse insect communities available for insectivorous birds (Burger et al. 1990; Millenbah et al. 1996).

Plant community characteristics, such as the density and structure of vegetation, have been shown to influence bird use of grassland areas (Frawley and Best 1991; Delisle and Savidge 1997; Norment et al. 1999; Fisher and Davis 2010). Differences in plant community characteristics between grasslands that received biosolids and those that did not resulted in species-specific patterns of bird use between the biosolids and control plots in this study. Eastern meadowlarks were the most abundant bird using grassland habitats on the MCAS Cherry Point airfield. Meadowlarks (omnivore: ground forager) were commonly observed using both control and biosolids-treated grasslands throughout the year, although they were nearly twice as abundant in biosolids-treated areas compared to control areas. These birds were likely using the denser vegetation (primarily tall fescue) in the biosolids-treated monitoring plots for nesting, singing perches, or foraging (Bollinger 1995; Lanyon 1995; Warren and Anderson 2005). American robins (omnivore: ground forager) and European starlings (omnivore: ground forager) were observed primarily 
during winter months (e.g., December to March) and almost exclusively in plots that received biosolids, potentially because these grasslands provided a specific foraging opportunity for these species (e.g., plant seeds or insects). In contrast, swallows used control plots (insectivore: air screener) more than biosolids-treated plots, suggesting that the insect resources associated with untreated grassland areas were more favorable to these birds.

White-tailed deer did not exhibit a preference between control and biosolids-treated grasslands and used both grassland habitat types equally. The majority of white-tailed deer diets are comprised of broad-leaved herbaceous plants (e.g., clovers [Trifolium spp. L.], common dandelion [Taraxacum officinale G. H. Weber ex Wiggers]) and woody plants, with relatively small amounts of grass consumed (Nixon et al. 1970; Korschgen et al. 1980; Rose and Harder 1985). Washburn and Seamans (2007) found that decreasing forbs and legumes (via herbicide applications) reduced white-tailed deer use of cool-season grasslands. The biosolids-treated grassland areas were dominated by grasses, which resulted in low amounts of forage available for white-tailed deer in those areas. In contrast, control grasslands had more plant species diversity and thus potentially contained more forage for deer. Interestingly, differences in available forage resources within biosolids-treated and control grassland areas did not appear to influence use of those areas by deer. White-tailed deer were observed in the grasslands on the MCAS Cherry Point airfield throughout the year, but used those grassland habitats more during winter and spring months. Overall, the distribution of white-tailed deer using grassland areas on the airfield appears to be related to natural corridors and landscape features rather than the specific botanical composition of airfield grassland habitats. Not unexpectedly, white-tailed deer typically used grassland areas located further from areas of high human activity (e.g., aircraft hangers, buildings).

\section{MANAGEMENT IMPLICATIONS}

Long-term application of biosolids to grasslands altered plant community characteristics and wildlife use of study plots. Overall, long-term application of biosolids resulted in plant communities that were simpler in botanical composition. Responses by grassland wildlife to long-term biosolids application and the associated changes in vegetation were speciesspecific and related to foraging guilds of grassland birds. Additional research is needed to determine if and how plant community and wildlife responses to land application of biosolids might vary among exotic and native grassland and rangeland system types, among geographic areas, and among other species of wildlife.

Land managers and planners considering the use of grasslands as a disposal site for municipal biosolids should also consider wildlife responses (both potentially positive and negative) during decision-making processes and cost-benefit analyses. Depending on the goals and objectives associated with wildlife resources within exotic cool-season and native grasslands areas, disposal of biosolids might be a useful mechanism for accomplishing species-specific habitat management objectives for grassland wildlife, in particular for certain grassland birds.

\section{ACKNOWLEDGMENTS}

USDA Wildlife Services employees D. Akom, K. Cobble, and K. Yankus provided field assistance for the study. We thank the MCAS Cherry Point for providing access to the airfield (study sites) and information related to biosolids disposal at the facility. We thank T. DeVault, B. Blackwell, T. Seamans, J. Millspaugh, and two anonymous reviewers for helpful comments on this manuscript.

\section{LITERATURE CITED}

Barnes, T. G., L. A. Madison, J. D. Sole, and M. J. Lacki. 1995. An assessment of habitat quality for northern bobwhite in tall fescue-dominated fields. Wildlife Society Bulletin 23:231-237.

BolLINGER, E. K. 1995. Successional changes and habitat selection in hayfield bird communities. Auk 112:720-730.

BonнAm, C. E. 1989. Measurements for terrestrial vegetation. New York, NY, USA: John Wiley and Sons. $338 \mathrm{p}$.

Burger, L. W., E. W. Kurzejeski, T. V. Dailey, and M. R. Ryan. 1990. Structural characteristics of vegetation in CRP fields in northern Missouri and their suitability as bobwhite habitat. North American Wildlife and Natural Resources Conference 55:74-83.

Cogger, C. G., A. I. Bary, S. C. Fransen, and D. M. Sullivan. 2001. Seven years of biosolids versus inorganic nitrogen applications to tall fescue. Journal of Environmental Quality 30:2188-2194.

Degraff, R. M., N. G. Tilghman, and S. H. Anderson. 1985. Foraging guilds of North America birds. Environmental Management 9:493-536.

Delisle, J. M., AND J. A. Savidge. 1997. Avian use and vegetation characteristics of conservation reserve program fields. Journal of Wildlife Management 61:318-325.

Dutch, J., And R. Wolstenholme. 1994. The effects of sewage sludge application to a heath land site prior to planting with Sitka spruce. Forest Ecology and Management 66:151-163.

Evanylo, G. K., A. 0. Abaye, C. Dundas, C. E. Zipper, R. Lemus, B. Sukkariyah, and J. RoсkEтT. 2005. Herbaceous vegetation productivity, persistence, and metal uptake on a biosolids-amended mine soil. Journal of Environmental Quality 34:1811-1819.

Fisher, R. J., and S. K. Davis. 2010. From Wiens to Robel: a review of grasslandbird habitat selection. Journal of Wildlife Management 74:265-273.

Frawley, B. J., AND L. B. BeSt. 1991. Effects of mowing on breeding bird abundance and species composition in alfalfa fields. Wildlife Society Bulletin 19:135-142.

Fresquez, P. R., R. E. Francis, and G. L. Dennis. 1990. Soil and vegetation responses to sewage sludge on a degraded semiarid broom snakeweed/blue grama plant community. Journal of Range Management 43:325-331.

Gaskin, J. W., R. B. Brobst, W. P. Miller, and E. W. Tollner. 2003. Long-term biosolids application effects on metal concentrations in soil and bermudagrass forage. Journal of Environmental Quality 32:146-152.

GoodwIn, R. A. 1989. Soil survey of Craven County, North Carolina. Washington, DC, USA: US Dept of Agriculture, Natural Resources Conservation Service. 162 p.

Henry, C. L., D. W. Cole, and R. B. Harrison. 1994. Use of municipal sludge to restore and improve site productivity in forestry: The Pack Forest Sludge Research Program. Forest Ecology and Management 66:137-149.

Kiemnec, G. L., T. L. Jackson, D. D. Hemphill, and V. V. Volk. 1987. Relative effectiveness of sewage sludge as a nitrogen fertilizer for tall fescue. Journal of Environmental Quality 16:353-356.

Korschgen, L. J., W. R. Porath, and 0. Torgerson. 1980. Spring and summer foods of deer in the Missouri Ozarks. Journal of Wildlife Management 44:89-97.

Lanyon, W. E. 1995. Eastern meadowlark (Sturnella magna). In: A. Poole and F. Gill [EDS.]. The birds of North America, No. 160. Philadelphia, PA, USA: The Birds of North America, Inc. 23 p.

Lerch, R. N., K. A. Barbarick, D. G. Westfall, R. H. Follett, T. M. McBride, and W. F. OWEN. 1990. Sustainable rates of sewage sludge for dryland winter wheat production. I. Soil nitrogen and heavy metals. Journal of Production Agriculture 3:60-65. 
Levine, M. B., A. T. Hall, G. W. Barrett, and D. H. Taylor. 1989. Heavy metal concentrations during ten years of sludge applications to an old-field community. Journal of Environmental Quality 18:411-418.

Maguire, R. 0., J. T. Sims, and F. J. Coale. 2000. Phosphorus solubility in biosolidsamended farm soils in the mid-Atlantic region of the USA. Journal of Environmental Quality 29:1225-1233.

Mata-González, R., R. E. Sosebee, and C. Wan. 2006. Effect of types of biosolids and cattle manure on desert grass growth. Rangeland Ecology \& Management 59:664-667.

Meyer, V. F., E. F. Redente, K. A. Barbarick, R. B. Brobst, M. W. Paschke, and A. L. MilLer. 2004. Plant and soil responses to biosolids application following forest fire. Journal of Environmental Quality 33:873-881.

Millenbah, K. F., S. R. Winterstein, H. Campa III, L. T. Furrow, and R. B. Minnis. 1996. Effects of Conservation Reserve Program field age on avian relative abundance, diversity, and productivity. Wilson Bulletin 108:760-770.

Moreno-Penaranda, R., F. Lloret, and J. M. Alcaniz. 2004. Effects of sewage sludge on plant community composition in restored limestone quarries. Restoration Ecology 12:290-296.

Nixon, C. M., M. W. McClain, and K. R. Russell. 1970. Deer food habits and range characteristics in Ohio. Journal of Wildlife Management 34:870-886.

Norment, C. J., C. D. Ardizzone, and K. Hartman. 1999. Habitat relations and breeding biology of grassland birds in New York. Studies in Avian Biology 19:112-121.

Ralph, C. J., J. R. Sauer, and S. Droege. 1995. Monitoring bird populations by point counts. Albany, CA, USA: US Dept of Agriculture, Forest Service, General Technical Report, PSW-GTR-149. $181 \mathrm{p}$.

Robel, R. J., J. N. Briggs, A. D. Dayton, and L. C. Hulbert. 1970. Relationships between visual obstruction measurements and weight of grassland vegetation. Journal of Range Management 23:295-297.

ROSE, J., AND J. D. HARDER. 1985. Seasonal feeding habits of an enclosed high density white-tailed deer herd in northern Ohio. Ohio Journal of Science 85:184-190.
Schafale, M. P., and A. S. Weakley. 1990. Classification of the natural communities of North Carolina, third approximation. Raleigh, NC, USA: North Carolina Natural Heritage Program, Division of Parks and Recreation. $231 \mathrm{p}$.

SOPPER, W. E. 1993. Municipal sludge use in land reclamation. London, United Kingdom: Lewis Publishers. $176 \mathrm{p}$.

[USDA] US Department of Agriculture, [ITIS] Integrated Taxonomic Information SySTEM. 2009. The Integrated Taxonomic Information System (ITIS) on-line database. Available at: http://www.itis.usda.gov. Accessed 16 June 2009.

[USEPA] US Environmental Protection Agency. 1993. Standards for the use or disposal of biosolids. Federal Register 58:9248-9415.

Vasseur, L., C. Cloutier, and C. Ansseau. 2000. Effects of repeated sewage sludge application on plant community diversity and structure under agricultural field conditions on Podzolic soils in eastern Quebec. Agriculture, Ecosystems, and Environment 81:209-216.

WarRen, K. A., And J. T. Anderson. 2005. Grassland songbird nest-site selection and response to mowing in West Virginia. Wildlife Society Bulletin 33:285-292.

Washburn, B. E., T. G. Barnes, and J. D. Sole. 2000. Improving northern bobwhite habitat by converting tall fescue fields to native warm-season grasses. Wildlife Society Bulletin 28:97-104.

Washburn, B. E., S. C. Barras, and T. W. Seamans. 2007. Foraging preferences of captive Canada geese related to turfgrass mixtures. Human-Wildlife Conflicts 1:188-197.

Washburn, B. E., and T. W. Seamans. 2007. Wildlife responses to vegetation height management in cool-season grasslands. Rangeland Ecology \& Management 60:319-323.

White, C. S., S. R. Loftin, and R. Aguilar. 1997. Application of biosolids to degraded semiarid rangeland: nine-year responses. Journal of Environmental Quality 26:1663-1671.

ZaR, J. H. 1996. Biostatistical analysis. 3rd ed. Upper Saddle River, NJ, USA: Prentice-Hall. $662 \mathrm{p}$. 